\title{
BEYOND THE SENTENCE IN SECONDARY EDUCA- TION: A CASE STUDY OF DISCOURSE ANALYSIS IN L2 WRITINGS ${ }^{24}$
}

\author{
Rosa Muñoz Luna, Universidad de Málaga ${ }^{25}$ \\ Email: rmluna@uma.es
}

\begin{abstract}
Learning to write in a foreign language requires the mastery of L2 discursive items. However, teaching practices in the field have traditionally focused on a grammatical level, leaving other macro-linguistic aspects aside such as coherence and cohesion. In this paper, we are analysing the written academic discourse of a group of intermediate-level students of English to see how textual structures actually affect their final written output in L2. In order to obtain a coherent and cohesive text, explicit language awareness must be fostered in class on a daily basis: the teaching of $\mathrm{L} 2$ writing needs to be meaning-based so that text composition becomes more flexible and natural.
\end{abstract}

Keywords: L2 discourse, macrolinguistics, microlinguistics, writing, awareness.

Título en español: "Más allá del nivel oracional en la E.S.O.: estudio de caso de análisis del discurso de textos en L2"

Resumen: Aprender a escribir en una lengua extranjera requiere dominar los elementos discursivos en la L2. Sin embargo, las corrientes pedagógicas de enseñanza de lenguas tienden a centrarse en un nivel gramatical, dejando estos aspectos discursivos de lado tales como la coherencia y la cohesión. En este artículo, analizamos el discurso académico de un grupo de estudiantes españoles de nivel intermedio de inglés para ver cómo las estructuras textuales influyen en el escrito final en L2. Con el fin de obtener un texto coherente y cohesivo, se necesita trabajar la conciencia lingüística en clase a diario: la enseñanza del inglés como L2 debe ser significativa para que la composición de textos pueda ser más flexible y natural.

Palabras clave: discurso L2, macrolingüística, microlingüística, escritura, concienciación.

\section{INTRODUCTION AND CONTEXT}

The aim of this paper is to develop an empirical case study investigation of discourse beyond the sentence level in a set of written productions in L2; secondary students' aca-

\footnotetext{
24 Date of reception: 19 September 2014

Date of acceptance: 18 November 2014

25 The present research has been funded by the Spanish Ministry of Education within the FPU programme (grant reference AP2007 - 03689). This grant is hereby gratefully acknowledged. I also want to thank Dr. Sarah Rich at Exeter University for her valuable corrections on earlier versions of this paper.
} 
demic writings are being analysed regarding their elements of textual cohesion, coherence and curricular expectations. These written discursive issues deserve an outstanding place within the curriculum due to the importance of writing in academic life. In fact, students' writing behaviour and output will determine their chances of proceeding to and succeeding in further education, as most of their entry examinations and evaluations are written.

The written scripts we are going to describe in this paper have been produced by a group of Spanish students at the end of their secondary education period. Their overall curricular level is very good, and their English levels at the time of writing these scripts are intermediate (B1). These high-scoring students have been chosen for being representative for highest academic performance. These research subjects present no relevant problems when writing in English as L2, however, their written expression is still worth analysing, as we may find writing errors and mistakes susceptible to change. Although they are the most proficient writers in their class groups, there is a level beyond the sentence which still presents inadequacies. This level includes defining features regarding the way students write in English as L2; even though these learners do not make disrupting grammatical mistakes, yet their L2 discourse contains coherence issues which deserve closer attention.

Our interest in the topic of writing skills arose after analysing Pisa report results (2001), revealing the position of Spanish students regarding other students in Europe. According to this information, Spanish learners are the lowest-scoring students in terms of academic results, and they are especially poor regarding written comprehension and production in both L1 and L2. In order to shed some light on this writing problem, we want to examine L2 written discourse beyond the sentence level, trying to identify explicit features which improve the overall script quality.

The students whose writings we are examining here are high-intermediate level learners aged between 17 and 18 years old. English subject is part of their compulsory school modules, and it has been being so since primary education. The subjects show a high degree of motivation towards English, taking part in all optional assignments the teachers propose in class. In fact, their L2 written level is high, with very few grammatical mistakes. However, thanks to the present language analysis, we aim to categorize weaker areas in L2 written discourse at intermediate level, focusing on those textual aspects which are not only morpho-syntactic but which also construct a coherent text written by skilled L 2 writers.

The present paper is structured as follows: we first introduce basic notions on written discourse in the light of the recent literature. Secondly, we contextualise curricular discourse items within the Spanish academic curriculum. For the scope of discourse analysis developed here, we are employing textual evaluation criteria divided into three academic categories: micro-linguistics (cohesive deixis), macro-linguistics (beyond the sentence coherence) and their relation to the academic curriculum in secondary education. Finally, we use these analyses to comment on the weakest discursive areas found, trying to offer some suggestions to improve our own teaching practice at both secondary and tertiary levels. This study is therefore related to the field of pragmalinguistics, something that Nattinger and DeCarrico define as the analysis of discourse in the light of Pragmatics (1992): in this case, the pragmatic side of discourse analysis comes with pedagogical consequences of the analysis, in other words, teaching implementations that would improve linguistics beyond the sentence in L2 writings. 


\section{THEORETICAL FRAMEWORK}

Conscious and systematic analysis of written discourse did not take place until the second half of the $20^{\text {th }}$ century (McKay 2006). Previous studies had mainly focused on either syntactic or morphological features, leaving aspects on text construction aside. Nevertheless, foreign language proficiency is not only determined by the grammatical choice of the word but also by the correct achievement of the text purpose. This is so because texts are multidimensional productions, and therefore such complex nature needs a holistic study approach. Cohesion, coherence, and the achievement of text intended meaning, that is, the way sentences and ideas are naturally interwoven, conform the body and the essence of a text.

For the purpose of this paper, we should distinguish between discourse, text and context. In this regard, discourse is "a continuous stretch of language larger than a sentence, often constituting a coherent unit" (Nunan, 1993: 5), whereas "text is a piece of naturally occurring [...] discourse identified for purposes of analysis" (Nunan, 1993: 6). Finally, the context "refers to the situation giving rise to the discourse" (7). The three of them, discourse, text and context, are located on an ascending scale where context determines the other two. At the same time, the form and purpose of the text will establish the type of discourse students are required to use.

McKay (2006: 101) provides a description for discourse analysis and she defines it as "discourse context of interactions". Moreover, this author proposes some criteria to evaluate discourse: oral discourse first, and then in the written form, which are contextual (macrolinguistic) as well as textual and discursive (macro and micro-linguistic) (McKay 2006). Other considerations on discourse analysis can also be found in Celce-Murcia and Olshtain (2000), whose categories have been used in our analysis. Text linguistics is normally the leading field in the analysis of written discourse; however, we should mention cognitive and second language sciences as factors affecting the way a written text is produced.

The discourse analysis carried out in this study takes place from an academic perspective, that is, academic language is being analysed for academic purposes (the texts written by the subjects were part of their formative evaluation in class). Within this academic standpoint, certain discursive markers (i.e. discursive segments) are being examined, which connect the various topics in an essay and give coherence to the whole text. In fact, there are so many aspects involved in discourse production that the field is multidisciplinary. For practical and effective purposes, only some text features are taken into account in this analysis; these aspects will be our text evaluation criteria in order to identify discursive marks in L2 written texts.

Discourse analysis is the "study of speaker meaning [...] and the study of contextual meaning" (Yule, 1996: 3). This area of analysis focuses on how language is used (in any form) to express some particular intention. Current trends in discourse analysis focus on the social construction of the text as an interactive tool for communication; as Hyland (2005: 177) indicates, "writing is embedded in wider social and discursive practices that carry assumptions about participant relationships". Other research studies also focus on the social approach towards teaching written discourse (see Davidson 2007). For a more 
detailed description of the different trends in teaching writing, Yeo (2007) offers a diachronic account of the way discourse has been taught throughout time.

When linking discourse awareness and discourse analysis, we find the work by John, Boucouvalas y Xu $(2006,185)$, who developed the "Theory of emotional momentum" to demonstrate that these variables are interrelated. Moreover, Alm (2008) has recently analysed affective markers in both written and oral discourse.

Constructivism is especially relevant in those cases where non-native speakers aim to be successful in L2 speaking/writing (Nagowah \& Nagowah, 2009). Particular cognitive schemata need to be developed in those processes: not only the linguistic barrier impedes fluent discourse, but also academic genre rules need to be constructed under foreign frameworks. For this reason, constructivist learning/teaching takes place progressively but meaningfully, and it does so at different levels of knowledge.

From morphology to syntax, and then to textual construction: that is the theoretical framework that supports this study, which focuses on the various linguistic elements that are necessary to make an L2 text meaningful.

\section{WRITTEN DISCOURSE IN ENGLISH AS L2: THE IMPORTANCE OF EXPLICIT LAN- GUAGE AWARENESS}

Contrastive studies (English-Spanish) on event reporting have been developed both in written and spoken discourse (Mora Gutiérrez 2001; Morimoto 2001; Caballero 2007). Those research projects which focus on written skills have carefully considered the relationship between lexical quality and writing quality (Agustín Llach \& Terrazas Gallego 2009; Schmitt 2000). However, although good vocabulary management is a reliable quality indicator, it is not the only relevant aspect in giving quality to a written composition: discursive cohesion and coherence (or how words relate beyond the sentence) are also determining to achieve proficiency in writing.

L2 writing implies closer attention to form, since in this case the student is writing in a language s/he might not feel confident at (Nattinger \& DeCarrico 1992). Consequently, aspects such as creativity, ideas flow and content are easily forgotten, resulting in a poorer and less engaging production. Bilton and Sivasubramaniam (2009), in their search for L2 written creativity, have proven that emotional and personal engagement in a text increases motivation.

Writing search for creativity inevitably leads us to the topic of language awareness. As already mentioned by Bolitho et al. (2003: 256), "language awareness approaches place high value on the creative and situated use of language". In the set of written productions analysed for this paper, all proposed essay topics are highly engaging and student-related (i.e. pets, social life, family life, vegetarians, smoking and men vs. women, among others). In this way, student-writers can easily identify themselves with their texts, paying equal attention to both form and content and bridging that gap that seems to be very often ignored when writing in a foreign language.

As far as the subjects' written compositions are concerned, we can actually find some instances of expressivity and involvement in the way they express their ideas: as we will see later on, they demonstrate explicit language awareness in the way they employ dis- 
cursive markers and adverbs; at the same time, there is a personal attachment to the text topic, inviting them to write from personal experiences and thus making the writing task more rewarding.

\section{WRITTEN DISCOURSE IN THE SPANISH SYLLABUS OF ENGLISH AS A SECOND LANGUAGE (ESL) IN SECONDARY EDUCATION}

The way in which written discourse is approached within the Spanish ESL syllabus can be described as highly decontextualised. In opposition to Thornbury's (2005) pedagogical suggestions, the teaching of written discourse does not happen (when it does) in context. On a general basis, Spanish secondary students do not receive real-world written models to follow or to be inspired by in the classroom, but they rather learn certain fixed structures to insert throughout their texts without examining the concatenation of ideas in them.

Some years ago, and in a non Spanish setting, Beach and Bridwell (1984: 185) already claimed that "much of the writing students do in schools will not achieve real world ends" (italics added). Writing for real world purposes implies teaching not only anecdote writing -the most taught text type so far-but also other types of written genres (e.g. newspaper articles, diaries, personal notes, emails, resumes, etc.). As a consequence, these students may have problems in recognising genre features, something that can pose obstacles for their own L2 production and also for their reading comprehension. In order to provide students with necessary genre tools, we suggest improving their sense of written accuracy regarding discourse recognition by teaching discourse types explicitly and extensively in the class.

Moreover, Cook (1989: 23) considers that grammatical "formal links are not enough". We have to take into account language functions, which will depend on the different genres. These language functions can be labelled as 'writing acts', in a parallel description with 'speech acts' in spoken conversation. These acts should be taught and practised in the L2 classroom as a crucial part within the official syllabus design.

\section{DISCOURSE ANALYSIS METHODOLOGY: EVALUATION CRITERIA USED IN THIS PAPER AND STUDY RESULTS}

In order to analyse the subjects' written productions, we have chosen certain evaluation criteria that correspond to different discursive mechanisms present in the students' texts. These try to cover aspects which are both internal and external to the text. The evaluation criteria described in this paper can be divided into three categories:

a. Those evaluating the curriculum - student production correspondence: Does the student's written output reflect, whether positively or negatively, the curricular aspects meant to be covered? Are discursive issues considered within the academic curriculum?

b. Those evaluating texts from a macro-linguistic perspective: Which are the elements giving coherent entailment to the text? How should EFL teachers approach discursive structural schemata in class? 
c. Those dealing with micro-linguistic aspects: What are the morphological items which express deictic reference? How is cohesion achieved within the sentence?

Inspired by previous research on academic discourse analysis, we elaborated a list of discursive items to be examined. These included linguistic features covering both linguistic forms and functions. We are looking for patterns that occur at various textual levels: from single words (lexical level) up to segments or sentences (grammatical and discursive levels).

\subsection{Curriculum-related criteria}

Several authors have recently selected specific evaluation criteria in order to analyse the quality of language teacher training programmes (Peacock 2009). These assessment points were certainly illuminating when deciding my evaluation criteria for students' written production. In this case, these assessment criteria are particularly inspiring when observing how real classroom production in L2 corresponds to the official academic curriculum.

Even though discursive competence is considered to be key in developing full communicative competence (Celce-Murcia \& Olshtain 2000), discourse issues are not formally included in Spanish EFL curricula. Since they are not explicitly taught, they are not explicitly assessed either.

In addition, the type of register that is normally taught is the one corresponding to a neutral style. In other words, neither slang nor highly formal and academic registers are offered to EFL students in the classroom. Later on in this paper, we suggest some pedagogical implications to change the current situation regarding teaching discourse, with the inclusion of what we consider to be some of the basic genre features in writing.

\subsection{Macro-linguistic criteria}

After considering the existing discursive gap in the Spanish EFL academic curriculum, we will examine structural issues of the text itself. More specifically, we will analyse the notions of coherence and cohesion, pillars in the world of L2 discourse analysis. Firstly, the concept of entailment is closely related to coherence, as they both refer to the concatenation of ideas throughout the paragraphs. Entailment is "something that logically follows from what is asserted in the utterance" (Yule, 1996: 25); this textual tool makes the text flow naturally and logically into sequences.

In this case, the subjects' output reveals a clear thematic connection between one sentence and the next; however, due to their lack of deictic resources, there is some degree of word repetition used to keep thematic coherence. In all of the students' productions the thematic thread is followed throughout the whole text, where topic and structure simplicity help for this purpose.

As far as the structure of written production is concerned, Stekauer et al. (2007) provide an onomasiological approach in favour of focusing on the meaning rather than on the form of the text. For this purpose, it is necessary to bring into consideration Cook's (1989: 69) notion of mental schemata, defined as: "mental representations of typical situations [...] used to predict the contents of the particular situation which the discourse describes". 
These mental patterns determine the way something is expressed by following cognitive models which derive from our previous world experience (Nunan 1993). Consequently, it is not only language what we have to teach; the teacher's task includes introducing new mental discourse representations without invalidating students' Spanish schemas. In this manner, learners will be able to make predictions in relation to textual organisation procedures in English, and therefore produce more natural L2 texts.

The formal teaching of rhetorical and structural patterns in essay writing is prescriptive in many ways (Davidson \& Spring 2008). We can see how these students' productions clearly follow the 'introduction + body + conclusion' pattern, even though that may result in artificial, decontextualised and repetitive text divisions; L2 learners are taught text organisation by structuring their written productions into well-defined sections, what might produce non-flexible compositions. Furthermore, this rigid frame implies paying attention to text sections instead of focusing on a semantic coherence. For this reason, since the study subjects lack proper linking devices, their writing flow can be rather unnatural for certain topics: we can see that some conclusions are too short or the essay is clearly form-driven, leaving the meaning aside.

Stronger writers are able to compose complex sentences while weak ones do not write long phrases. For the latter, it seems they are not ready to do so, or they do not feel ready to use English so freely. As Coll, et al. (2007) indicate, students' self-concept is what ultimately motivates them to achieve a better performance. Only in skilled writers is there a clear structural layout in their written scripts: high-scoring students structure their production in clearer paragraphing and in a sequential order: e.g. definition, typology, explanation, and conclusion. For this reason, texts are more than cognitive procedures: they are key instruments of communication between the reader and the writer.

\subsection{Micro-linguistic criteria}

As far as smaller units of analysis are concerned, we want to examine the way deictic reference is expressed in these students' written discourses. Deixis can be defined as indications of spatial, personal or temporal references in discourse (Yule 1996); at the same time, these indications can be proximal, distal or deictic centred depending on the speaker's or writer's perspective.

Regarding cohesion, these students employ some linking words such as: however (indicating contrast), first of all (enumeration), consequently (effect), in short (summarising). According to these examples -and following the different types of cohesive devices identified by McCarthy (1993) - it is mainly the phenomenon of reference what we find in these writings, that is, words that are used to refer to something previously or immediately afterwards mentioned.

When applying deictic criteria to the student writings, we can see that these do not present a wide range of spatial and temporal markers. Personal pronouns are used to indicate involvement in the topic but not many references are provided to refer to previous or subsequent ideas. Rather than providing synonyms or periphrastic devices, subjects repeat whole phrases resulting in a more artificial flow of sentences; an example of this can be found in the following excerpt about youngsters drinking alcohol on the street. Even 
though the text is grammatically correct in almost every sentence, the sense of repetition is present throughout:

I am against the big bottle, because I think there are more forms to enjoy. A person can do sport, go to the theatre, read a good book, to go for a ride to the mountain or the beach, swim at the sea... to enjoy. But in my opinion, it is so stupid for a person to stop at the street for drink. Scientists say that drink alcohol is not healthy [...]. In conclusion, I am against the big bottle because a person can spend life without drink alcohol. Subject 1.

Nattinger and DeCarrico explain this phenomenon of redundancy and repetition by stating that L2 writing practice implies a slower processing of linguistic data, "which results in inefficient use of redundancy and contextual cues" (1992: 159). In order to balance his lack of lexical resources, this student makes use of referential cohesion to keep textual consistency. As mentioned above, only personal and adverbial references are used, while, for example, "demonstrative reference" (Nunan, 1993: 21-23) and synonyms do not take place at all.

Likewise, the following second student clearly prefers repetition rather than taking risks and using demonstrative pronouns to refer to previously mentioned aspects. Her writing is, therefore, safe and correct, and very much concerned with the form her essays must have in order to get a high mark, which she finally receives. The following extract illustrates again a fixed textual structure, this time dealing with ways of leading a healthy life:

The Government can offer young people to encourage a healthy life sport activities as well as cultural ones, because to lead a healthy life is more than a body built. It is also to be cultivated. Activities like cheap gyms, big stadiums and free libraries or maths tournaments, for example, are very needed. In conclusion, the Government could help young people to lead a healthy life spending a little money on sport activities and cultural ones. Subject 2.

On the other hand, this shortage in deictic expressions is balanced with a number of adverbials, something that supports Caballero's (2007: 71) statement on Romance languages: "verbs are mainly concerned with trajectory or path, and additional information is expressed by means of adverbials"; as in subject 1 and 2's writings: "at the streets", "all the time", "from countries", "in meetings". Similar phenomena occur in Subject 3's sample:

I am against street pollution; in my opinion, cars, buses and airplane contaminate a lot. A car or a bus needs petrol to run, and people need cars and buses to go to different places. But in my opinion, it is so necessary to change this means of transport in the city. Contamination in the air of the city is a big problem [...]. In conclusion, I am against street pollution because we need other healthier ways to live. Subject 3.

Regarding other kinds of content words in a sentence, something that Nunan calls "lexical density" (1993: 11), we do not find many of them per syntactic proposition. His sentences are simple, not containing subordinate clauses, consequently avoiding the corresponding subordinate conjunction. As we can see, no errors appear on a grammatical or lexical level, but it is now the discursive level what would help to make his texts stronger in terms of proficient writing. 
By applying these evaluation criteria, I am focusing on low-productivity areas and low morphological productivity, opposing the tendency among scholars to measure high frequency items. Stekauer et al. (2007), aware of this lack of research in low productivity morphological fields, offer a tool to assess and quantify poor linguistic behaviour. This assessment instrument could be employed in later studies to make further analyses on this issue.

\section{WRITTEN EVIDENCE FROM STUDENTS' PRACTICE: WHAT TO IMPROVE IN L2 ACADEMIC WRITING}

\subsection{Weak areas in L2 writing at intermediate level}

As far as the essay structure is concerned, the Spanish EFL curriculum devotes little time for creativity. Students like the subjects of this research are taught in class to divide their written productions in three main sections, namely introduction + body + conclusion, without taking into account topic variations, content coherence and suitability. For this purpose, students do receive a set of linking words to be used in their writings, normally in the form of a list of items to be inserted in their class submissions. Nevertheless, students seem to use those expressions rather mechanically, without considering the context, cotext or overall meaning of the text. The negotiation/exposure of meaning is very often lost in the text.

In the case of these subjects' compositions, and despite they are proficient L2 writers, it is worth noticing the lack of lexical collocations in their written output. We consider that there might be several reasons for this textual simplicity: firstly, they have not examined any authentic model (e.g. real written text used for real purposes) previously in class, where they could have found some of those linking words used in context; secondly, lexical collocations are not contemplated as such in the academic curriculum of that course; finally, these students have not had the opportunity for practising collocations in different contexts and for various purposes during the academic year. We can say that students do not have enough cognitive constructions in their L2, that is, they sometimes fail when joining words and meanings.

These results are in line with previous research findings: Murphy (2008), who states that metacognitive strategies are linked to reflective behaviours in more autonomous learners. Moreover, better L2 academic writing results in a more coherent written expression. According to Kaufman (2004) and Peacock (2010), that is an indicator of a well-developed constructivist process, where coherence means an optimum achievement of new understandings. Those scripts presenting a higher number of cognitive and metacognitive elements include a wider range of specific purposes in their discourse, that is, explanations, descriptions, claims, etc.

\subsection{Suggestions for the teaching of foreign language written discourse}

In the light of this small-scale analysis, discourse needs to be included more explicitly in the academic curriculum prior to university entrance. Nattinger and DeCarrico provide the reasons why teaching discourse issues is highly recommendable (1992). Furthermore, 
written productions could be used as initial diagnostic tests in our classroom. By analysing students' L2 essays, teachers can easily find evidence for their weaknesses. For this purpose, written discourse analysis helps to identify certain areas which deserve deeper attention in class, both at macro and at micro linguistic levels.

Micro-linguistic items (morpho-syntactic structures) are a very significant part within the academic curriculum; however, that is not the case of macro-linguistic devices. It may be the case that a student employs the correct form (morphologically wide), but they do not success in transmitting the appropriate meaning. Here is where pedagogical support becomes crucial. When observing these students' work, we can see how important both levels (that is, word level and meaning level) are in forming written complex sentences in L2: cohesion, coherence, intended meaning construct meaningful sentences and, at the same time, are indicators of the students' writing mastery in English as a foreign language.

In secondary school contexts, where English courses could be described as English for General Purposes, some suggestions to be included in the teaching curriculum would be:

- How to write a formal essay

- How to write an informal letter

- How to write a business letter

In this way, we would be analysing several discursive aspects such as: notion of appropriacy, register, style and specific lexicon according to the genre. Using Arndt et al.'s words, we would be teaching "choices and combinations of words to fulfil specific purposes" (2000: 55). Contextualised practices like those would facilitate the combination of form and content, what results in more fluent writings.

Following Paltridge's etymology on genres and text types (1996), we would be covering some of the most important text types: exposition, anecdote and problem-solution structures. As we mentioned above, it is worth considering the teaching of new written schemata to the students, providing them with something beyond text sections and moving into genre types. Beach and Bridwell (1984) stress the fact that L2 writers apply the knowledge of their L1 world to their writings; therefore in this case, teachers' task is not to change whole conceptual images but rather adding new ways of expressing ideas in the written form.

For a more creative alternative in the teaching on writing, Grant et al. (2008) provide a different way of introducing written skills in the academic curriculum, linking them with artful forms of learning: role-plays, games and visualization, among others.

As far discourse evaluation is concerned, "traditional marking insists that equal attention be drawn to every error" (Thornton, 1980: 39). However, after analysing these productions in detail, we would make strong distinctions among the different discursive and grammatical categories. If we do an explicit teaching of coherence and cohesion devices, we will consequently assess them, giving specific symbols to each mistake type during my correction.

By indicating their mistake types, we would be teaching inductively, since students would have to work out their own mistakes and correct them. Some suggestions on how correcting inductively are provided by Byrne (1989). After reading King et al.'s (2008) assessment proposal, we would like to apply some of the portfolio system features to our own testing practice. Mainly for metacognitive reasons, keeping a portfolio can be a good 
way to have an updated record of the students' learning as well as an important source of measurable progress.

\section{CONCLUSIONS}

Raising language awareness implies taking into account many micro-linguistic and macro-linguistic issues of the language, being aware of when to use what specific linguistic devices to achieve a certain purpose. If teachers make a difference between the various genre types, learners will acquire the necessary linguistic instruments to create their own texts and apply them to their real life situations.

After the analysis of these students' writings, we conclude that L2 discourse awareness is necessary in order to produce successful and communicative language. Discursive aspects must be included in the academic EFL curriculum in an explicit way. Discourse analysis not only encourages language awareness but it also helps to make meaningful connections among the rest of the curricular items: morphological elements, together with cohesive devices, find a significant link in discourse, which is the perfect tool to bring all of them together.

\section{REFERENCES}

Alm, E. 2008. Affect in Text and Speech. Illinois: University of Illinois at UrbanaChampaign. Doctoral thesis.

Agustín Llach, M \& Terrazas Gallego, M. 2009. "Examining the Relationship between Receptive Vocabulary Size and Written Skills of Primary School Learners". Atlantis 31 (1): 129-147.

Arndt, V. Et Al. 2000. Alive to Language. Cambridge: Cambridge University Press.

BEACH, R. \& BRIDWELL, L. 1984. "Learning through Writing: a Rationale for Writing across the Curriculum". The Development of Oral and Written Language in Social Contexts. Eds. a. pellegrini and t. yawkey. New Jersey: Ablex. 183-198.

Bilton, L. \& Sivasubramniam, S. 2009. “An Inquiry into Expressive Writing: a Classroom-Based Study". Language Teaching Research 13 (3): 301-320.

Bolitho, R. Eт Al. 2003. “Ten Questions about Language Awareness”. ELT Journal 57 (3): 251-259.

Byrne, D. 1989. Teaching Writing Skills. Harlow: Longman.

CABALlERo, R. 2007. “Textual Input and Learning Outcomes: Enriching Input through Genre Analysis”. Atlantis 29 (1): 69-86.

Celce-Murcia, M.\& Olhstain, E. 2000. Discourse and Context in Language Teaching: a Guide for Language Teachers. Cambridge: Cambridge University Press.

Соок, G. 1989. Discourse. Oxford: Oxford University Press.

DAvidson, C. 2007. "Independent Writing in Current Approaches to Writing Instruction: What Have we Overlooked?" English Teaching: Practice and Critique 6 (1): 11-24. 
Davidson, P. \& SpRING, J. 2008. "Rhetorical Patterns in Academic Writing: Re-examining Conventional Wisdom". Teaching Writing Skills in EFL: Theory and Research. Eds. c. coombe et al. Dubai: TESOL Arabia. 27-40.

Grant, A. et al. 2008. "Creative Pedagogies: 'Art-Full' in Reading and Writing". English Teaching: Practice and Critique 7 (1): 57-72.

Hyland, K. 2005. Digging Up Texts and Transcripts: Confessions of a Discourse Analyst. Second Language Writing Research: Perspectives on the Process of Knowledge Construction. Eds. p. matsuda and t. silva. London: Lawrence Erlbaum. 177-189.

John, D. Boucouvalas, A.c. \& Xu, Z. 2006. "Representing Emotional Momentum within Expressive Internet Communication". Proceedings of the 24th IASTED International Conference on Internet and Multimedia Systems and Applications. Ed. a.c. boucouvalas. Anaheim, CA: ACTA Press. 183-188.

Kaufman, D. 2004. "Constructivist Issues in Language Learning and Teaching”. Annual Review of Applied Linguistics, 24, 303-319.

KING, C. Et Al. 2008. "Portfolio Assessment: Making Connections, Guiding Change". English Teaching: Practice and Critique 7 (3): 4-9.

Mccarthy, M. 1993. Discourse Analysis for Language Teachers. Cambridge: Cambridge University Press.

Mckay, S. 2006. Researching Second Language Classrooms. London: Lawrence Erlbaum.

Mora GutiérRez, J. 2001. "Directed Motion in English and in Spanish."<http://elies. rediris.es/elies 11>. Accessed 12 March 2012.

Morimoto, Y. 2001. Los verbos en movimiento. Madrid: Visor.

Murphy, L. 2008. "Supporting Learner Autonomy: Developing Practice through the Production of Courses for distance Learners of French, German, and Spanish". Language Teaching Research, 12(1), 83-102.

Nagowah, L. and Nagowah, S. 2009. "A reflection on the dominant learning theories: behaviourism, cognitivism and constructivism". International Journal of Learning, 16 (2), 279-286.

NAtTinger, J. \& Decarrico, J. 1992. Lexical Phrases and Language Teaching. Oxford: Oxford University Press.

Nunan, D. 1993. Introducing Discourse Analysis. London: Penguin.

Paltridge, B. 1996. "Genre, Text Type, and the Language Learning Classroom”. ELT Journal 50 (3): 237-243.

Peacock, M. 2009. "The Evaluation of Foreign-Language-Teacher Education Programmes". Language Teaching Research 13: 259-278.

Peacock, M. 2010. "Linking Adverbials in Research Articles across Eight Disciplines". Ibérica, 20, 9-34. 
PISA RePORT. 2001. "English Language Teaching and Learning Evaluation."

$<$ http://www.institutodeevaluacion.mec.es/contenidos/nacional/eso-lengua-inglesa. pdf $>$. Accessed 06 April 2011.

Schmit, N. 2000. Vocabulary in Language Teaching. Cambridge: Cambridge University Press.

Stekauer, P. et al. 2007. "How is Low Morphological Productivity Measured?". Atlantis 29 (1): 29-54.

Thornbury, S. 2005. Beyond the Sentence: Introducing Discourse Analysis. Oxford: Macmillan Education.

Thornton, G. 1980. Teaching Writing: the Development of Written Language Skills. London: Edward Arnold.

Yeo, M. 2007. "New Literacies, Alternative Texts: Teachers' Conceptualisations of Composition and Literacy". English Teaching: Practice and Critique 6 (1): 113-131.

Yule, G. 1996. Pragmatics. Oxford: Oxford University Press. 
